\title{
A new species of Tetragonopterus Cuvier, 1816 (Characiformes: Characidae: Tetragonopterinae) from the rio Jari, Amapá, northern Brazil
}

\author{
Bruno F. Melo, Ricardo C. Benine, Tatiane C. Mariguela and Claudio Oliveira
}

A new species of Tetragonopterus is described from the rio Jari, a tributary to the left margin of rio Amazonas, at the border between Amapá and Pará States, northern Brazil. It is morphologically diagnosed from the other species of the genus ( $T$. argenteus, $T$. chalceus, and T. rarus new combination) by the lozenge-shaped spot on the caudal peduncle vs. rounded to square spot on the other species. Partial sequences of the mitochondrial gene Cytochrome Oxidase C subunit I, from representatives of all valid species of Tetragonopterus, including this new species, were analyzed. The obtained results revealed a significant genetic distance between the new species and its congeners. A discussion on the new combination, Tetragonopterus rarus, is also provided.

Uma espécie nova de Tetragonopterus é descrita do rio Jari, um tributário da margem esquerda do rio Amazonas, na divisa entre os Estados do Amapá e Pará, norte do Brasil. Esta é morfologicamente diferenciada das outras espécies do gênero (T. argenteus, T. chalceus e T. rarus combinação nova) pelo formato losangular da mancha no pedúnculo caudal contra uma mancha arredondada a quadrangular nas demais espécies. Sequências parciais do gene mitocondrial citocromo oxidase C subunidade I de representantes de todas as espécies válidas de Tetragonopterus, incluindo esta espécie nova, foram analisadas. Os resultados obtidos revelaram uma significante distância genética entre esta espécie nova e as demais do gênero. É apresentada uma discussão sobre a nova combinação, Tetragonopterus rarus.

Key words: COI gene, Genetic distance, Mitochondrial DNA, Neotropical fish, Taxonomy.

\section{Introduction}

Tetragonopterus is widely distributed in the major cisAndean South America river drainages, such as Orinoco, Amazon, Araguaia, São Francisco, Paraguay, and Paraná Rivers (Reis, 2003), with all species externally characterized by a relatively deep and laterally compressed, transversely-flattened prepelvic region that is bordered laterally, particularly proximate to the pelvic-fin insertion, by distinctly-angled scales, a pronounced ventral curvature of the anterior portion of the lateral line, an anal fin with a long base, and a complete outer row of multicuspid teeth in the premaxilla (Benine et al., 2004).

Tetragonopterus comprises two valid species, $T$. argenteus Cuvier 1816, and T. chalceus Spix \& Agassiz, 1829. A third species, Tetragonopterus lemniscatus Benine, Pelição \& Vari, 2004 has been considered a junior synonym of Moenkhausia rara Zarske, Géry \& Isbrücker, 2004, but indeed both species are synonyms, there is no consensus on its generic allocation. We herein provide evidences that the species must be placed in Tetragonopterus as a new combination, Tetragonopterus rarus (Zarske, Géry \& Isbrücker, 2004). These species can be differentiated from each other by the number of median scales between the tip of the supra-occipital spine and the base of the first dorsal-fin ray ( 13 to 17 scales in T. argenteus $v s .8$ to 12 scales in T. chalceus and T. rarus) and by the color pattern (presence of longitudinal dark stripes in T. rarus vs. absence in T. argenteus and T. chalceus).

Sequences of the mitochondrial DNA cytochrome oxidase $\mathrm{C}$ subunit 1 (COI gene), with approximately 650 base-pairs, have been extensively used for species identification. Through this method, known as DNA barcode (Hebert et al., 2003), it is possible to discriminate a wide variety of species, considering that the intraspecific variation in this sequence is much lower than the

Laboratório de Biologia e Genética de Peixes, Departamento de Morfologia, Instituto de Biociências, Universidade Estadual Paulista (UNESP, Câmpus de Botucatu). Rubião Jr., s/n, 18618-970 Botucatu, SP, Brazil. melo@ibb.unesp.br, rbenine@ibb.unesp.br, tatimariguela@gmail.com, claudio@ibb.unesp.br 
interspecific variation (Hebert et al., 2003; Ward, 2009). DNA Barcode has been employed to assist morphological data in new species descriptions (see Victor 2007; Pyle et al., 2008; Benine et al., 2009).

In the present study we combine morphological analysis with molecular identification to examine the representatives of the three species of Tetragonopterus and a new species from rio Jari, a tributary of the left margin of the lower rio Amazonas. The aim of the present contribution is to describe this new species and provide an analysis of the genetic distance among Tetragonopterus species. A discussion on the new combination, Tetragonopterus rarus (Zarske, Géry \& Isbrücker, 2004), is also provided.

\section{Material and Methods}

The material examined in this study is deposited in the Academy of Natural Sciences (ANSP), Philadelphia; California Academy of Sciences (CAS), São Francisco; Instituto Nacional de Pesquisas da Amazônia (INPA), Manaus, AM; Laboratório de Biologia e Genética de Peixes, Universidade Estadual Paulista (LBP), Botucatu, SP; Laboratório de Ictiologia de Ribeirão Preto, Universidade de São Paulo (LIRP), Ribeirão Preto, SP; Museu de Ciências Naturales de Guanare (MCNG), Guanare; Museu de Ciências e Tecnologia, Pontifícia Universidade Católica do Rio Grande do Sul (MCP), Porto Alegre, RS; Museum of Comparative Zoology, University of Harvard (MCZ), Cambridge; Museu de Zoologia da Universidade de São Paulo (MZUSP), São Paulo, SP; National Museum of Natural History, Smithsonian Institution (USNM), Washington, DC.

Morphometric and meristic data were taken following Fink \& Weitzman (1974) and Benine et al. (2004) from 57 specimens (holotype and 56 paratypes) and made whenever possible on the left side of the specimens using a digital caliper (precision of $0.01 \mathrm{~mm}$ ). Individual meristic values in the description are followed by their frequency in parentheses, with values for holotype indicated by asterisks. Gill rakers counts are presented according to the formulae: lower limb gill rakers, joint fluctuant gill raker, upper limb gill rakers. Measurements are given as proportions of standard length (SL) except for portions of the head that are presented as proportions of head length (HL). The last two anal-fin rays that are joined at the base were counted as one element. Four specimens were cleared and stained (c\&s) according the method of Taylor \& van Dyke (1985).

Vouchers of the used material in molecular analysis are deposited at LBP fish collection. Total genomic DNA was extracted from ethanol-preserved tissue muscle using method described by Aljanabi \& Martinez (1997). Partial sequences of COI gene were obtained from 19 individuals of Tetragonopterus using the following primers designed: $\mathrm{COI}$ L6252-Asn (5'-AAG GCG GGG AAA GCC CCG GCA G -3') and H7271-COXI (5'- TCC TAT GTA GCC GAA TGG TTC TTT T -3'). Amplifications were performed in a solution with a total volume of $25 \mu \mathrm{l}$ with $19.8 \mu \mathrm{l}$ ultrapure $\mathrm{H}_{2} \mathrm{O}, 2.5 \mu \mathrm{Taq}$
DNA buffer (10X), $0.4 \mu \mathrm{l}$ dNTP $(8 \mathrm{mM}), 0.5 \mu \mathrm{MgCl}_{2}(10 \mathrm{mM})$, $0.5 \mu \mathrm{l}$ primer $\mathrm{L} 6252$-Asn and $0.5 \mu \mathrm{l}$ primer $\mathrm{H} 7271-\mathrm{COXI}, 0.2 \mu \mathrm{l}$ Taq polymerase enzyme and $1.0 \mu 1$ genomic DNA(10-50 ng). The polymerase chain reaction (PCR) consisted of a initial denaturation $\left(4 \mathrm{~min}\right.$ at $95^{\circ} \mathrm{C}$ ) followed by 35 cycles with chain denaturation $\left(30 \mathrm{~s}\right.$ at $\left.95^{\circ} \mathrm{C}\right)$, primers hybridization $\left(45 \mathrm{~s}\right.$ at $\left.50^{\circ} \mathrm{C}\right)$ and nucleotide extension $\left(45 \mathrm{~s}\right.$ at $\left.72^{\circ} \mathrm{C}\right)$. After the cycles, we performed a final extension at $72^{\circ} \mathrm{C}$ for 10 minutes. The PCR products were identified in a $1 \%$ agarose gel, and then amplified segments were purified using ExoSap-IT $₫$ enzyme (USB Corporation) following instructions of the manufacturer. Sequencing reactions were performed with the BigDyeTM Terminator v.3.1 Cycle Sequencing Ready Reaction (Applied Biosystems) and analyzed on an ABI $3130^{\mathrm{TM}}$ DNA Sequencer (Applied Biosystems).

All sequences were read at least twice (forward and reverse). Individual sequences of each sample were analyzed using BIOEDIT 5.0.9 (Hall, 1999) and a consensus sequence was obtained for all samples. All sequences were aligned with MUSCLE software (Edgar, 2004). Genetic distances were estimated with the Kimura-2-parameter model (Kimura, 1980). Neighbor-joining tree (Saitou \& Nei, 1987) and phylogenetic analyses based on maximum-parsimony (MP) method (Swofford \& Berlocher, 1987) were performed using the program MEGA 4.0 (Kumar et al., 2004). Calculations of transitions, transversions and nucleotide frequencies were conducted in MEGA 4.0; saturation analysis was performed in DAMBE (Xia \& Xie, 2001). The resultant topologies were statistically tested by the bootstrap method (Felsenstein, 1985) with 1,000 pseudoreplicates.

All DNA sequences from samples used in molecular analysis were deposited in GenBank (accession numbers HM070382 to HM070400 - www.ncbi.nlm.nih.gov/GenBank).

\section{Tetragonopterus carvalhoi, new species Fig. 1}

Holotype. MZUSP 102268, 36.5 mm SL, undetermined sex, Brazil, Amapá, Laranjal do Jari, Igarapé Iratapuru, rio Jari, Amazon basin, 00'33'30"S 52 34'45'W, 14 Oct 2007, M. R. Carvalho, A. Akama, C. Oliveira \& F. Marques.

Paratypes. LBP 5306, 7, 33.5-45.8 mm SL, Brazil, Amapá, Laranjal do Jari, Igarapé Iratapuru, rio Jari, Amazon basin, 00³4’03”S 52 $34^{\circ} 41^{\prime \prime}$ W, 11 Oct 2007, M. R. Carvalho, A. Akama, C. Oliveira \& F. Marques (Genbank numbers HM070389 to HM070393). LBP 5376, 34 (4 c\&s), 29.7-45.8 mm SL, Brazil, Amapá, Laranjal do Jari, Igarapé Iratapuru, rio Jari, Amazon basin, 00³3'51' $\mathrm{S}$ 52 $34^{\circ} 45^{\prime}$ 'W, 10 Oct 2007, M. R. Carvalho, A. Akama, C. Oliveira \& F. Marques. MZUSP 106813, 15, 34.2-41.9 mm SL, same data as the holotype.

Diagnosis. Tetragonopterus carvalhoi can be diagnosed from its congeners by the lozenge-shaped spot on the caudal peduncle, extending from the vertical through the beginning of adpressed adipose fin to the median caudal-fin rays $v s$. rounded to square-shaped spot confined to the posterior half of caudal peduncle (Fig. 2). Tetragonopterus carvalhoi further 


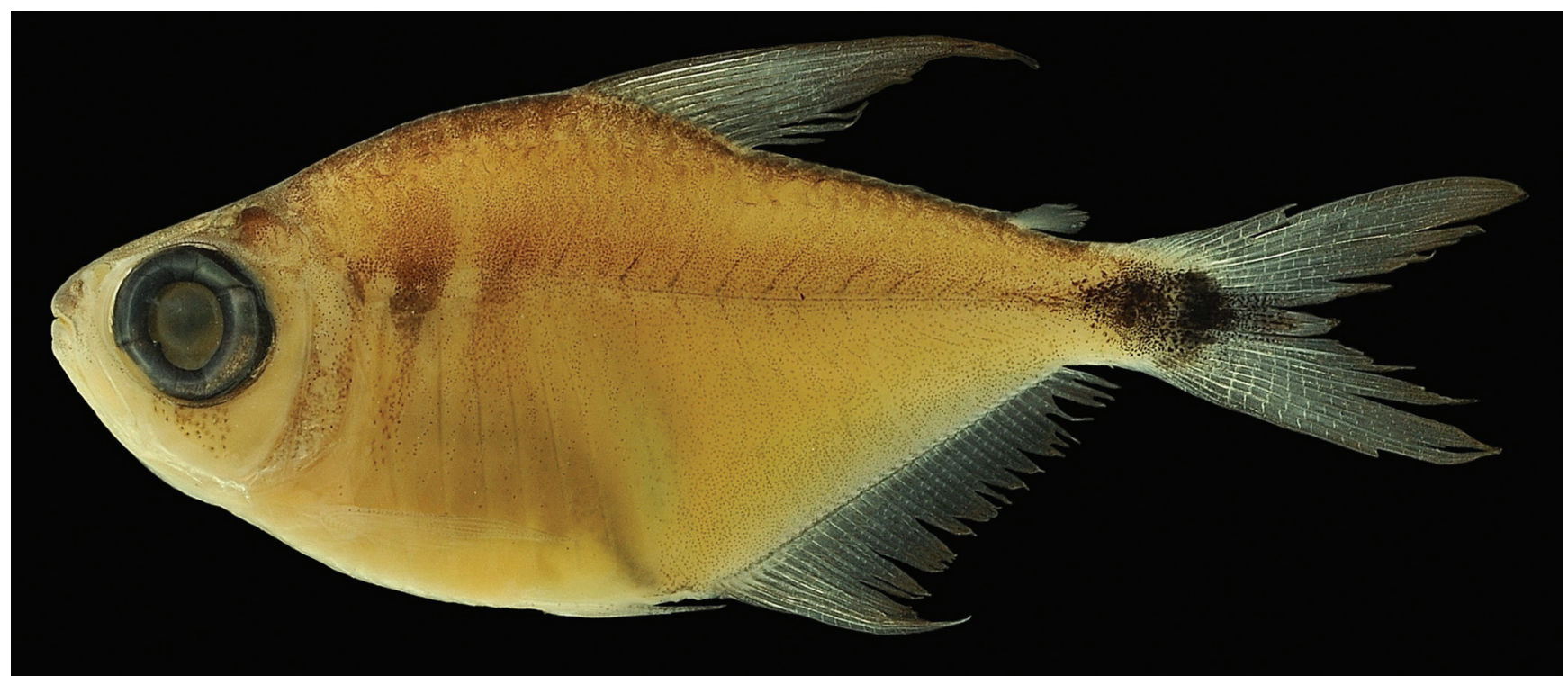

Fig. 1. Tetragonopterus carvalhoi, holotype, MZUSP 102268, undeterminated sex, 36.5 mm SL: Brazil, Amapá State, Laranjal do Jari, Igarapé Iratapuru, rio Jari, Amazon basin.

differs from $T$. argenteus by the number of predorsal scales (6-10 vs. 12-16, respectively) and from $T$. rarus by the absence of dark longitudinal stripes on the lateral surface of the body (vs. present).

Description. Morphometric data given in Table 1. Largest specimen $45.8 \mathrm{~mm}$ SL. Compressed body, proportionally deep. Greatest depth at vertical through origin of dorsal fin. Dorsal profile of head straight to slightly concave above orbit. Each nostril closer to anterior margin of orbit than to each other. Supraoccipital spine elongate, but tip of spine not extending beyond vertical through posterior of opercle. Dorsal profile of body convex from tip of supraoccipital spine to posterior terminus of base of dorsal fin; straight to slightly convex from that point to end of base of adipose fin; caudal peduncle profile slightly concave both dorsally and ventrally. Ventral profile of body convex from tip of lower jaw to origin of caudal peduncle. Prepelvic region of body transversely flattened, with flattening more pronounced proximate to pelvic-fin insertion. Scales along lateral margins of flattened region immediately anterior to insertion of pelvic fin with distinct angle.

Mouth terminal. Premaxillary teeth in two rows; outer row with $4(8), 5^{*}(45), 6$ (3), or 7 (1) tricuspid teeth; inner row with $4(2), 5^{*}(51)$ or 6 (4) relatively compressed, pentacuspid teeth, except from the central pair which presents tetracuspidated. Maxilla with 2(1), $3^{*}(29), 4(22), 5(4)$, or 7(1) tri- to pentacuspid teeth. Dentary with $4 *(55)$ or 5 (2) pentacuspid large teeth gradually decreasing in size. Remaining dentary teeth considerably smaller, conical to tricuspid.

Dorsal-fin rays ii, $9 *$ (57). Anal-fin rays iv,29 (3), 30 (9), 31 (18), 32* (23), 33 (2), or 34 (2); last unbranched and first branched anal-fin rays more elongated; posterior remaining anal-fin rays decreasing gradually in length. Pectoral-fin rays $\mathrm{i}, 12(8), 13^{*}(48)$, or 15 (1); tip of pectoral fin extending beyond vertical through insertion of pelvic fin. All specimens with $\mathrm{i}, 7^{*}$ rays in pelvic fin.

Scales cycloids. Lateral line with 29 (2), 30* (23), 31 (25), or 32 (7) pored scales with its anterior portion distinctly curved. Median scales between tip of supraoccipital spine and base of first ray of dorsal fin $6(2), 7(10), 8(37), 9 *(7)$, or 10 (1). Scale rows between dorsal-fin origin and lateral line $7^{*}(55)$ or 8 (2). Scale rows between lateral line and pelvic-fin insertion 3.5 (26) or 4* (31). Single or double row of small scales covering base of anal fin. Scales around caudal peduncle $11(2), 12(1), 13^{*}(34)$ or $14(20)$. First gill arch with $9,1,12(12) ; 9,1,13 *(36) ; 9,1,14(3) ; 10,1,13$ (4); or 10,1,14 (2) gill rakers. Vertebrae 28 (4).

Coloration in alcohol. Overall ground coloration yellowish tan. Dorsal portion of head, nape, and portion of middorsal region of body anterior and posterior to base of dorsal fin darker. A scattered field of dark chromatophores below orbit mainly on second and third infraorbital bones. Two conspicuous vertical dark marks on humeral region. Anterior humeral mark more evident than posterior humeral mark. Anterior humeral mark, located over second to fourth lateral line scales and vertically extending over 4 horizontal scale rows above lateral line, lateral line, and 2 horizontal scale rows below lateral line. Posterior humeral mark located over fifth and sixth lateral line scales and vertically extending over 4 horizontal scale rows above lateral line and lateral line; dorsal half of both humeral marks wider and more densely pigmented. Limits of posterior epaxial and hipoaxial miomeres enhanced by dark pigments, more evident at area of horizontal septum from just posterior second humeral mark to origin of caudal peduncle, resulting in a chevron-like pattern along lateral of body. A sparse field of dark chromatophores surrounding 

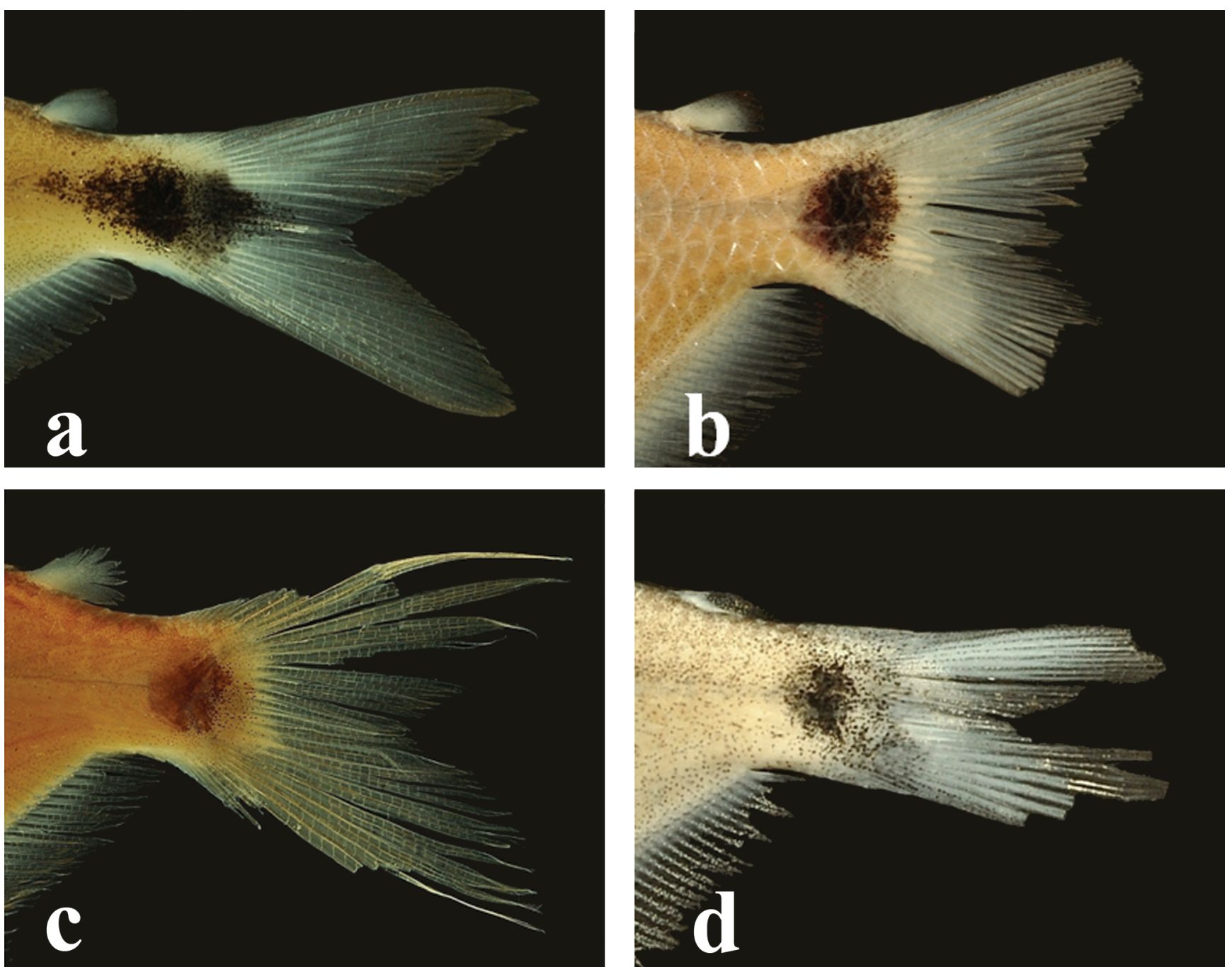

Fig. 2. Caudal peduncle evidencing dark spots of (a) Tetragonopterus carvalhoi, paratype, MZUSP 102268, 39.9 mm SL (rio Jari); (b) T. argenteus, LBP 3758, $60.8 \mathrm{~mm}$ SL (rio Negro); (c) T. chalceus, MZUSP 35008, $67.9 \mathrm{~mm}$ SL (rio Araguari); (d) T. rarus, LBP 5375, $38.0 \mathrm{~mm}$ SL (rio Jari).

horizontal septum and resulting in an unconspicuous lateral band. Distal margin of unpaired rayed-fins scattered with small dark chromatophores throughout extension. Pectoral and pelvic fins with scattered dark chromatophores, more concentrated on lateral unbranched rays. Adipose fin with very few dark chromatophores. Caudal peduncle with a large, lozenge-shaped dark spot extending from vertical through end of adpressed adipose fin to median caudal-fin rays.

Distribution. Tetragonopterus carvalhoi is known from the rio Jari, upstream from the Cachoeira de Santo Antônio, rio Amazonas drainage, Amapá, northern Brazil (Fig. 3).

Etymology. The specific epithet is in honor of Marcelo Rodrigues de Carvalho (USP), the leader of the expedition to rio Jari which resulted in the collection of this new species and in recognition of his contributions to our knowledge of the Neotropical ichthyology.
Molecular analysis. DNA sequences were obtained from tissues of following samples: Tetragonopterus argenteus LBP 3758 (5), LBP 3058 (2), LBP 3059 (1), LBP 5535 (1); Tetragonopterus carvalhoi LBP 5306 (5 paratypes); Tetragonopterus chalceus LBP 264 (4), and Tetragonopterus rarus LBP 5375 (1). The sequences from 19 specimens resulted in a matrix with 779 base pairs (bp) from which 617 positions were conserved, and 161 were variable. 118 positions were parsimony informative. The nucleotide frequencies were $30.9 \%$ thymine/uracil, $24.7 \%$ cytosine, $24.6 \%$ adenine and $19.8 \%$ guanine. Graphical analyses does not show any saturation in transitions or transversions. The overall transition/transversion rate was 3.9. Genetic distances (Kimura, 1980) range from zero among specimens of Tetragonopterus chalceus from São Francisco basin to 0.125 \pm 0.019 between $T$. carvalhoi and T. rarus, both from rio Jari (Table 2). Figure 4 presents the neighbor-joining majorityrule consensus tree with bootstrap values for 1,000 
Table 1. Morphometric data of Tetragonopterus carvalhoi. Range and $\mathrm{N}$ includes holotype and paratypes. $\mathrm{SD}=$ Standard deviation.

\begin{tabular}{|c|c|c|c|c|}
\hline & Holotype & Range & Mean & SD $\mathrm{N}$ \\
\hline Standard length $(\mathrm{mm})$ & 36.5 & $29.6-45.8$ & 36.6 & -57 \\
\hline \multicolumn{5}{|c|}{ Percents of Standard length } \\
\hline Greatest body depth & 49.7 & $44.3-52.4$ & 47.8 & 1.857 \\
\hline Snout to dorsal-fin origin & 53.0 & $49.1-56.0$ & 52.4 & 1.457 \\
\hline Snout to pectoral-fin origin & 30.9 & 24.9-33.7 & 30.4 & 1.057 \\
\hline Snout to pelvic-fin insertion & 50.4 & $46.6-52.8$ & 49.4 & 1.357 \\
\hline Snout to anal-fin origin insertion & 66.0 & $62.9-69.3$ & 66.0 & 1.557 \\
\hline Caudal peduncle depth & 11.1 & $8.6-12.1$ & 10.8 & 0.657 \\
\hline Caudal peduncle length & 7.0 & 4.4-9.4 & 7.0 & 1.157 \\
\hline Pector: & 26.0 & $23.0-28.8$ & 25.3 & 1.156 \\
\hline Pelvi & 20.6 & $14.5-22.4$ & 20.2 & 1.356 \\
\hline Dor: & 41.6 & $34.2-43.0$ & 39.6 & 2.153 \\
\hline & & $13.9-17.5$ & 15.6 & 0.857 \\
\hline & .4 & 28.2 & 24.9 & 2.150 \\
\hline & 39.1 & $35.7-41.3$ & 38.4 & 1.357 \\
\hline Orbit & 37.7 & $32.6-38.0$ & 36.3 & 1.057 \\
\hline Dor & 57.3 & $53.8-60.6$ & 56.2 & 1.557 \\
\hline Head 1 & 32.1 & $30.2-34.0$ & 31.7 & 0.957 \\
\hline Head depth & 24.3 & $22.1-25.6$ & 24.0 & 0.857 \\
\hline \multicolumn{5}{|c|}{ Percents of Head length } \\
\hline Snou & 20.6 & 18.3 & 21.6 & \\
\hline Upper jaw length & 45.4 & $40.7-48.9$ & 45.4 & 1.557 \\
\hline Horizontal orbital diameter & 53.3 & $50.0-57.2$ & 53.2 & 1.657 \\
\hline Least interorbital width & 31.3 & $27.8-33.0$ & 30.6 & 1.257 \\
\hline
\end{tabular}

pseudoreplicates which has the same topology observed in MP analyses. Three monophyletic groups (T. carvalhoi, $T$. chalceus, and $T$. argenteus) presented well-supported by values equal or higher than $97 \%$ in both methods of phylogenetic analysis.

\section{Discussion}

Zarske \& Géry (2006) recognized Tetragonopterus lemniscatus Benine, Pelição \& Vari, 2004 as a junior synonym of Moenkhausia rara Zarske, Géry \& Isbrücker, 2004. Indeed, comparing both original descriptions, there is no reason to doubt that $T$. lemniscatus is a junior synonym of $M$. rara but there is no consensus on its generic allocation. Zarske \& Géry (2006) argued that $M$. rara does not present the mainly diagnostic feature of the genus Tetragonopterus, the anterior portion of the lateral line accentually downward decurved, as proposed by Eigenmann (1917). In fact, the downward curvature degree of the lateral line in this species

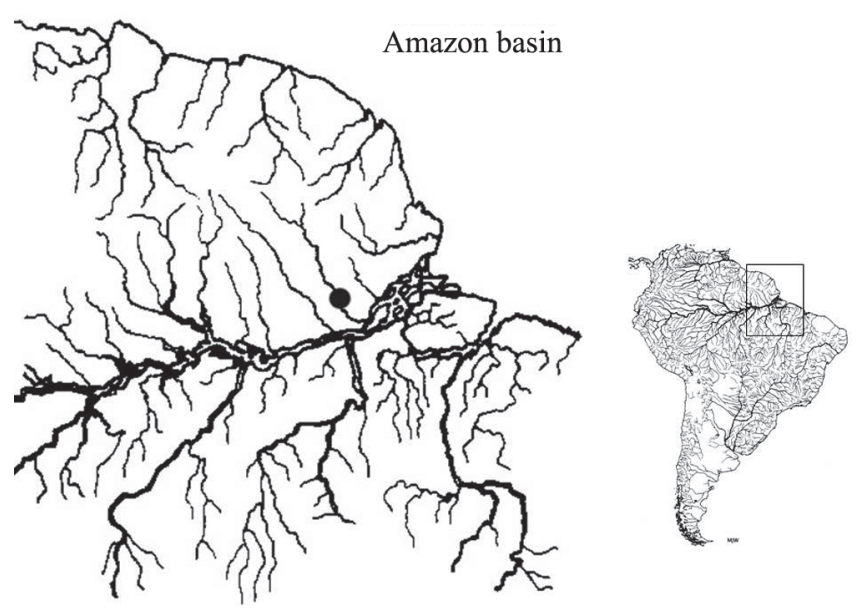

Fig. 3. Lower rio Amazonas indicating the position of the type locality of Tetragonopterus carvalhoi in rio Jari.

is quite variable, and never as accentuated as in both $T$. argenteus and $T$. chalceus. Notwithstanding, other morphological features indicate a putatively closer relationship of M. rara with T. argenteus, T. chalceus, and $T$. carvalhoi than between $M$. rara and $M$. xinguensis (type species of Moenkhausia), and with any other species of the genus. Mirande (2010) described a branched laterosensory canal of sixth infraorbital as an autapomorphy of $T$. argenteus (the only species of the genus examined by that author). This feature is also present in T. chalceus, T. carvalhoi, and $M$. rara and absent in $M$. xinguensis and also in any other species of Moenkhausia herein examined. In addition, $M$. rara shares with T. argenteus, T. chalceus, and T. carvalhoi the presence of only three supraneural bones. None examined species of Moenkhausia, except for M. georgiae (a species already recognized by Géry (1977) as "strongly resembling Tetragonopterus chalceus") present such a counting. Thus, we herein employed the new combination, Tetragonopterus rarus, as the valid name for Moenkhausia rara Zarske, Géry \& Isbrücker, 2004 and Tetragonopterus lemniscatus Benine, Pelição \& Vari, 2004.

The molecular analysis indicated a close relationship between Tetragonopterus carvalhoi and T. chalceus. In fact, these species can be morphologically differentiated only by

Table 2. Genetic distance (mean \pm standard error) among fishes of each locality (diagonal) and among samples from different localities (below diagonal). Numbers after species names are GenBank accession numbers.

\begin{tabular}{|c|c|c|c|c|c|c|}
\hline & 1 & 2 & 3 & 4 & 5 & 6 \\
\hline $\begin{array}{l}1 \text { Tetragonopterus carvalhoi Amazon basin - rio Jari } \\
\text { HM070389 to HM } 070393\end{array}$ & $0.001 \pm 0.000$ & & & & & \\
\hline $\begin{array}{l}2 \text { Tetragonopterus chalceus São Francisco basin } \\
\text { HM070382 to HM070385 }\end{array}$ & $0.087 \pm 0.012$ & $0.000 \pm 0.000$ & & & & \\
\hline $\begin{array}{l}3 \text { Tetragonopterus argenteus Orinoco basin } \\
\text { HM070386 to HM070388 }\end{array}$ & $0.112 \pm 0.014$ & $0.113 \pm 0.014$ & $0.022 \pm 0.004$ & & & \\
\hline $\begin{array}{l}4 \text { Tetragonopterus argenteus Paraguay basin - rio Negro } \\
\text { HM070394 to HM070398 }\end{array}$ & $0.103 \pm 0.013$ & $0.100 \pm 0.013$ & $0.057 \pm 0.008$ & $0.013 \pm 0.003$ & & \\
\hline $\begin{array}{l}5 \text { Tetragonopterus argenteus rio Parnaíba } \\
\text { HM070399 }\end{array}$ & $0.107 \pm 0.015$ & $0.107 \pm 0.015$ & $0.053 \pm 0.009$ & $0.042 \pm 0.008$ & $0.000 \pm 0.000$ & \\
\hline $\begin{array}{l}6 \text { Tetragonopterus rarus Amazon basin - rio Jari } \\
\text { HM070400 }\end{array}$ & $0.125 \pm 0.019$ & $0.104 \pm 0.017$ & $0.105 \pm 0.017$ & $0.106 \pm 0.016$ & $0.113 \pm 0.019$ & $0.000 \pm 0.000$ \\
\hline
\end{tabular}




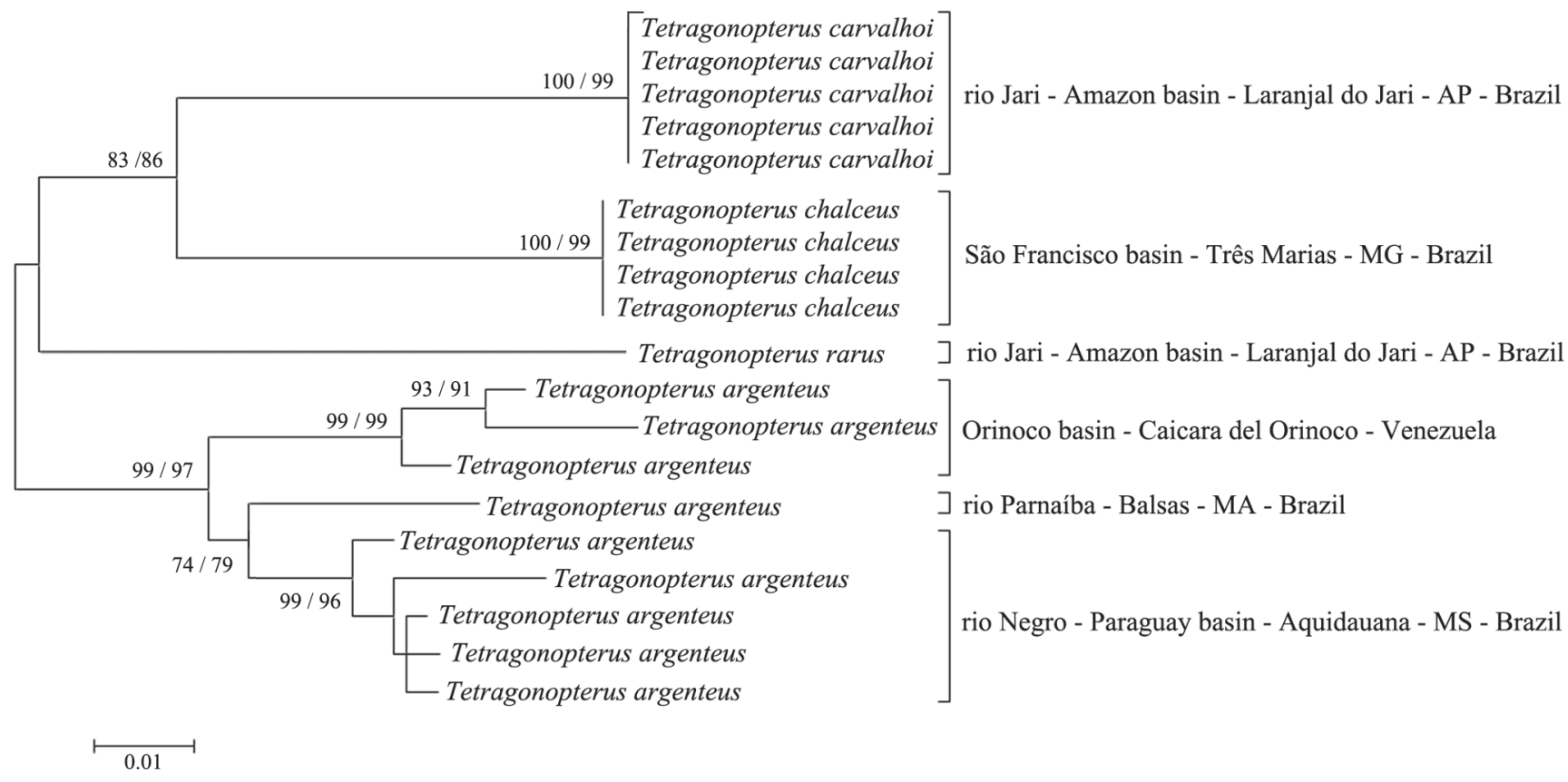

Fig. 4. Unrooted neighbor-joining majority-rule consensus tree for the mitochondrial gene Cytochrome Oxidase C subunit I evidencing a high genetic distance (Kimura-2-parameter) among species. First number on branches represents indexes of bootstrap by 1,000 pseudoreplicates for neighbor-joining method and second number represents indexes of bootstrap by 1,000 pseudoreplicates for maximum-parsimony. Values $\leq 50 \%$ are not shown.

the format of the peduncular spot (see Diagnosis). However, the observed value of genetic distance between these two species is $0.087 \pm 0.012$, while intraspecific genetic distance is $0.001 \pm 0.000$ in $T$. carvalhoi and $0.000 \pm 0.000$ in T. chalceus (Table 2). Recent general DNA barcoding studies with fishes have shown that differences larger than ten times between the intraspecific and the interspecific genetic distance usually characterizes species in this group (Ward et al., 2005; Hubert et al., 2008; Valdez-Moreno et al., 2009; Ward et al., 2009) which is consistent with the values observed here. The genetic distances between $T$. carvalhoi and $T$. argenteus, and between T. carvalhoi and T. rarus are even higher, varying from 0.103 \pm 0.013 to $0.112 \pm 0.014$ (for T. argenteus); and $0.125 \pm 0.019$ (for T. rarus) showing a significant genetic differentiation inside the Tetragonopterus. Another interesting result is the large variation observed among samples of $T$. argenteus from different localities in South America (Fig. 4). Although additional data are necessary for a better understanding of this variation, it is possible to suggest that $T$. argenteus represent a species complex with at least two undescribed species.

Comparative material. Moenkhausia barbouri: USNM 305457 , 2, 53.0-64.2 mm SL, rio Curiraba, Depto. Beni, Bolívia; Moenkhausia bonita: USNM 326473, 3, 23.5-31.0 mm SL, rio Jauru, tributary to rio Paraguay, Mato Grosso, Brazil; Moenkhausia browni: MZUSP 17140, 2, 30.4-37.6 mm SL, igarapé Apeu, Castanhal, Pará, Brazil; Moenkhausia ceros: USNM 307322, 2, 36.7-37.0 mm SL, lago Janauri, Amazonas, Brazil; Moenkhausia chrysargyrea: USNM 226155, 2, 52.3-49.3 mm SL, Nickerie District, Suriname; Moenkhausia colletti: MZUSP 34652 ,
2, 31.5-34.0 mm SL, rio Negro, Amazonas, Brazil; Moenkhausia copei: MZUSP 30263, 2, 30.9-35.2 mm SL, rio Uraricoera, Maracá, Roraima, Brazil; Moenkhausia costae: MZUSP 54705, 2, 40.2$45.5 \mathrm{~mm}$ SL, rio Carnaíba, Bom Jesus da Lapa, Bahia, Brazil; Moenkhausia cotinho: MZUSP 29829, 2, 24.2-25.0 mm SL, rio Negro, Barcelos, Amazonas, Brazil; Moenkhausia crisnejas: CAS 60577, 3 syntypes, 30.2-35.1 mm SL, rio Crisnejas, Paipay, Peru; Moenkhausia dichroura: LIRP 250, 1, $47.3 \mathrm{~mm}$ SL, rio Pardo, Ribeirão Preto, São Paulo, Brazil; Moenkhausia doceana: MZUSP 54777, 2, 43.9-47.3 mm SL, rio Bamburral, São Mateus, Espírito Santo, Brazil; Moenkhausia dyktiota: MZUSP 62615, 1, rio Negro, Amazonas, Brazil; Moenkhausia georgiae: ANSP 177000, 1, 48.4 mm SL, rio Siparuni, Essequibo, Guyana; Moenkhausia gracilima: USNM 310357, 2, 29.8-30.4 mm SL, rio Solimões, Amazonas, Brazil; Moenkhausia grandisquamis: MZUSP 30267, 2, 46.3$50.4 \mathrm{~mm}$ SL, rio Marauiá, Amazonas, Brazil; Moenkhausia hemigrammoides: MZUSP 30531, 1, $35.8 \mathrm{~mm}$ SL, rio Branco, Roraima, Brazil; Moenkhausia intermedia: LIRP 346, 2, 46.350.4 mm SL, Estação Ecológica de Jataí, Luís Antônio, São Paulo, Brazil; Moenkhausia jamesi: MCZ 20734, 1 syntype, $51.6 \mathrm{~mm}$ SL, lagoa do Máximo, Amazonas, Brazil; Moenkhausia justae: MZUSP 55752, 1, 45.6 mm SL, rio Branco, Roraima, Brazil; Moenkhausia lepidura: MZUSP 34627, 2, 60.8-64.6 mm SL, rio Negro, Amazonas, Brazil; Moenkhausia levidorsa: INPA 13259, 2, 40.8-59.2 mm SL, igarapé do Aeroporto, Brazil; Moenkhausia lopesi: LIRP 4642, 1, $37.8 \mathrm{~mm} \mathrm{SL}$, rio Piquiri, Mato Grosso do Sul, Brazil; Moenkhausia melogramma: USNM 310776, 2, 25.2$46.0 \mathrm{~mm}$ SL, rio Madeira, Amazonas, Brazil; Moenkhausia oligolepis: MZUSP 30287, 2, 43.1-59.1 mm SL, rio Cupixu, Amapá, Brazil; Moenkhausia phaeonota: LIRP 3046, 3, 26.2-44.2 mm SL, rio Arinos, Mato Grosso, Brazil; Moenkhausia pittieri: $\mathrm{MCNG}$ 140301, 1, 42.2 mm SL, Venezuela; Moenkhausia sanctaefilomenae: 
LIRP 717, 2, 33.4-34.9 mm SL, rio Cuiabá, Cuiabá, Mato Grosso, Brazil; Moenkhausia shideleri: MCNG 16904, 2, 26.8-36.7 mm SL, rio Cuyuni, Bolivar, Venezuela; Moenkhausia tergimacula: MCP 20287, 1, 34.7 mm SL, rio Tocantins, Minaçu, Goiás, Brazil (1); Moenkhausia xinguensis: MZUSP 36806, 1, $46.8 \mathrm{~mm}$ SL, rio Xingu, Cachoeira do Espelho, Pará, Brazil. Tetragonopterus argenteus: LBP 3058, 1, $78.2 \mathrm{~mm}$ SL, Caicara del Orinoco, Bolívar, Venezuela; LBP 3758, 20, 47.5-67.1 mm SL, rio Negro, Paraguay basin, Aquidauana, Mato Grosso do Sul, Brazil; LBP 5535, 1, 72.9 mm SL, rio Parnaíba, Balsas, Maranhão, Brazil; MZUSP 102266, 1, 50.6 mm SL, rio Jari, Laranjal do Jari, Amapá, Brazil; Tetragonopterus chalceus: MZUSP 29817, 2, 42.2-44.2 mm SL, rio Negro, Amazonas, Brazil; MZUSP 35006, 8, 46.2-52.5 mm SL, rio Tapajós, São Luiz, Pará, Brazil; MZUSP 35008, 6, 57.394.3 mm SL, rio Araguari, Amapá, Brazil; MZUSP 35017, 5, 53.176.8 mm SL, rio Tapajós, São Luiz, Pará, Brazil; MZUSP 47352, 5, 29.1-31.8 mm SL, rio Japoré, São Francisco basin, Manga, Minas Gerais, Brazil; MZUSP 65485, 2, $37.943 .4 \mathrm{~mm} \mathrm{SL}$, rio Mindriveti, Brokopondo District, Suriname; MZUSP 89182, 4, 38.5-45.5 mm SL, rio Araguaia, Cocalinho, Mato Grosso, Brazil; MZUSP 99689, 1, $68.9 \mathrm{~mm}$ SL, rio Marowjine, Suriname. Tetragonopterus leminiscatus: USNM 225366, holotype, $47.5 \mathrm{~mm}$ SL, tributary to Sisa Creek, Nickerie District, Suriname; LIRP 4928, 2 c\&s paratypes, 47.5-47.9 mm SL, tributary to Sisa Creek, Nickerie District, Suriname; LIRP 4929, 1, 79.8 mm SL, tributary to Sisa Creek, Nickerie District, Suriname; USNM 224367, 2, 48.4-60.1 mm SL, tributary to Sisa Creek, Nickerie District, Suriname; USNM 374750, 4, 42.0-46.6 mm SL, tributary to Sisa Creek, Nickerie District, Suriname. Tetragonopterus rarus: LBP 5375, 1, 38.0 mm SL, rio Jari, Laranjal do Jari, Amapá, Brazil. Tetragonopterus sp.: LBP 1831, 1, $31.8 \mathrm{~mm} \mathrm{SL}$, rio Araguaia, Aragarças, Goiás, Brazil; LBP 3059, 2, 49.3-54.0 mm SL, Caicara del Orinoco, Bolívar, Venezuela; LBP 3981, 2, 40.9-42.7 mm SL, rio Araguaia, São Félix do Araguaia, Mato Grosso, Brazil; LBP 4011, 2, 57.2-57.5 mm SL, rio Araguaia, São Félix do Araguaia, Mato Grosso, Brazil; LBP 7756, 3, 31.9-48.8 mm SL, rio Araguaia, Cocalinho, Mato Grosso, Brazil; LBP 7770, 1, 67.6 mm SL, rio Araguaia, Cocalinho, Mato Grosso, Brazil.

\section{Acknowledgements}

The authors are indebted to Osvaldo T. Oyakawa (MZUSP) for the loan of material and curatorial assistance. We are also grateful to Ricardo Britzke for help in obtaining the comparative material and to Fábio F. Roxo for assistance with Figs. 1 and 2. The authors are financially supported by Fundação de Amparo à Pesquisa do Estado de São Paulo (FAPESP), Conselho Nacional de Desenvolvimento Científico e Tecnológico (CNPq), Coordenação de Aperfeiçoamento de Pessoal de Nível Superior (CAPES) and Fundação do Instituto de Biociências de Botucatu, Botucatu, SP (FUNDIBIO). This study is part of the FAPESP Thematic Project "Phylogenetic Relationships in Characidae (Ostariophysi: Characiformes) (Proc. 04/09219-6).

\section{Literature Cited}

Aljanabi, S. M. \& I. Martinez. 1997. Universal and rapid saltextraction of high quality genomic DNA for PCR-based techniques. Nucleic Acids Research, 25: 4692-4693.
Benine, R. C., T. C. Mariguela \& C. Oliveira. 2009. New species of Moenkhausia Eigenmann, 1903 (Characiformes: Characidae) with comments on the Moenkhausia oligolepis species complex. Neotropical Ichthyology, 7(2): 161-168.

Benine, R. C., G. Z. Pelição \& R. P. Vari. 2004. Tetragonopterus lemniscatus (Characiformes: Characidae), a new species from the Coratijn River basin in Suriname. Proceedings of the Biological Society of Washington, 117(3): 339-345.

Edgar, R. C. 2004. MUSCLE: multiple sequence alignment with high accuracy and high throughput. Nucleic Acids Research, 32 : 1792-1797.

Eigenmann, C. H. 1917. The American Characidae. Part I. Memoirs of the Museum of Comparative Zoology, 53(1): 1-102.

Felsenstein, J. 1985. Confidence limits on phylogenies: An approach using the bootstrap. Evolution, 39(4): 783-791.

Fink, W. L. \& S. H. Weitzman. 1974. The so-called Cheirodontin fishes of Central America with descriptions of two new species (Pisces: Characidae). Smithsonian Contributions to Zoology, 172: 1-46.

Géry, J. 1977. Characoids of the World. Neptune City, T. F. H. Publications, 672p.

Hall, T. A. 1999. BioEdit: a user-friendly biological sequence alignment editor and analysis program for Windows 95/98/NT. Nucleic Acids Symposium Series, 41: 95-98.

Hebert, P. D. N., A. Cywinska, S. L. Ball \& J. R. de Waard. 2003. Biological identifications through DNA barcodes. Proceedings of the Royal Society B: Biological Sciences, 270: 313-322.

Hubert, N., R. Hanner, E. Holm, N. E. Mandrak, E. Taylor, M. Burridge, D. Watkinson, P. Dumont, A. Curry, P. Bentzen, J. Zhang, J. April \& L. Bernatchez. 2008. Identifyng Canadian Freshwater Fishes through DNA Barcodes. PLoS ONE, 3(6): e2490.

Kimura, M. 1980. A simple method of estimating evolutionary rate of base substitutions through comparative studies of nucleotide sequences. Journal of Molecular Evolution, 16: 111-120.

Kumar, S., K. Tamura \& M. Nei. 2004. MEGA3: Integrated software for Molecular Evolutionary Genetics Analysis and sequence alignment. Briefings in Bioinformatics, 5: 150-163.

Mirande, J. M. 2010. Phylogeny of the family Characidae (Teleostei: Characiformes): from characters to taxonomy. Neotropical Ichthyology, 8(3): 385-568.

Pyle, R. L., J. L. Earle \& B. D. Greene. 2008. Five new species of the damselfish genus Chromis (Perciformes: Labroidei: Pomacentridae) from deep coral reefs in the tropical western Pacific. Zootaxa, 1671: 3-31.

Reis, R. E. 2003. Subfamily Tetragonopterinae. Pp. 212. In: Reis, R. E., S. O. Kullander \& C. J. Ferraris Jr. (Eds.). Check List of the Freshwater Fishes of South and Central America. Porto Alegre, Edipucrs, 729p.

Saitou, N. \& M. Nei. 1987. The neighbor-joining method: a new method for reconstructing phylogenetic trees. Molecular Biology and Evolution, 4(4): 406-425.

Swofford, D. L. \& S. H. Berlocher. 1987. Inferring evolutionary trees from gene frequency data under the principle of maximum parsimony. Systematic Zoology, 36(3): 293-325.

Taylor, W. R. \& G. C. van Dyke. 1985. Revised procedures for staining and clearing small fishes and other vertebrates for bone and cartilage. Cybium, 9(2): 107-119.

Valdez-Moreno, M., N. V. Ivanova, M. Elías-Gutiérrez, S. Contreras-Balderas \& P. D. N. Hebert. 2009. Probing diversity in freshwater fishes from Mexico and Guatemala with DNA barcodes. Journal of Fish Biology, 74: 377-402. 
Victor, B. C. 2007. Coryphopterus kuna, a new goby (Perciformes: Gobiidae: Gobiinae) from the western Caribbean, with the identification of the late larval stage and an estimate of the pelagic larval duration. Zootaxa, 1526: 51-61.

Ward, R. D. 2009. DNA barcode divergence among species and genera of birds and fishes. Molecular Ecology Resources, 9: 1077-1085.

Ward, R. D., R. Hanner \& P. D. N. Hebert. 2009. The campaign to DNA barcode all fishes, FISH-BOL. Journal of Fish Biology, 74: 329-356.

Ward, R. D., T. S. Zemlak, B. H. Innes, P. R. Last \& P. D. N. Hebert. 2005. DNA barcoding Australia's fish species. Philosophical Transactions of the Royal Society of London. Series B, Biological Sciences, 360: 1847-1857.

Xia, X. \& Z. Xie. 2001. DAMBE: Data analysis in molecular biology and evolution. Journal of Heredity, 92: 371-373.

Zarske, A. \& J. Géry. 2006. Zum Status einiger von Steindachner und Holly beschriebenen Fisch-Taxa (Teleostei: Characiformes: Characidae). Zoologische Abhandlungen (Dresden), 56: 3-14.

Zarske, A., J. Géry \& I. J. H. Isbrücker. 2004. Moenkhausia rara sp. n. -eine neue, bereits bestandsgefährdete Salmler-Art (Teleostei: Characiformes: Characidae) aus Surinam und Französisch Guayana mit einer ergänzenden Beschreibung von M. simulata (Eigenmann in Pearson, 1924). Zoologische Abhandlungen (Dresden), 54: 19-30.

Accepted October 2, 2010

Published March 31, 2011 